\title{
The Effect of Slow-Deep Breathing and Isometric Hand Grip Exercise on Blood Pressure of Patients With Hypertension
}

\author{
* $1^{\text {st }}$ Noor Rochmah Ida Ayu Trisno \\ Putri \\ Nursing Program \\ Universitas Harapan Bangsa \\ Purwokerto, Indonesia \\ noorrochmah@uhb.ac.id
}

\author{
$2^{\text {nd }}$ Tri Sumarni \\ Nursing Program \\ Universitas Harapan Bangsa \\ Purwokerto, Indonesia \\ trisumarni@uhb.ac.id
}

\begin{abstract}
Hypertension is a health problem in the community and requires specific care attention. The disease has an impact on reducing the quality of life and can be life threatening if not treated early. One of the nonpharmacological interventions of hypertension is Slow-Deep Breathing exercise and isometric hand grips. The purpose of this study was to determine the effect of Slow-Deep Breathing and isometric hand grips exercise on blood pressure for patients with hypertension. Pre - experiment with one group pretest post-test design was used in this study. Forty respondents were selected using purposive sampling done in Kembaran I Public Health Center working area. Data collected were analyzed using the Mann-Whitney and Wilcoxon test. The result showed that the statistics analysis of $p$ value of systolic and diastolic pressure is $<0,005$. There are changes in systolic blood pressure $(p$ value $=0,005$ ) and diastolic blood pressure $(p=0,018)$. The Wilcoxon analysis showed a decrease in systolic blood pressure ( $p$ value $=0,001$ ) and diastolic blood pressure $(p$ value $=0,016$ ). It can be concluded that slow-deep breathing and isometric hand grip exercise are effective in lowering blood pressure of patient with hypertension
\end{abstract}

Keywords- Slow-Deep Breathing, Isometric Handgrip, Blood Pressure, Hypertension

\section{INTRODUCTION}

Hypertension is a health problem that needs to be watched out for as a contributor to early death in developed countries. Untreated and uncontrolled hypertension can be at risk of complications such as heart problems, blood vessels and kidneys damages[1]. Hypertension is characterized by an increase in systolic and diastolic blood pressure. Systolic blood pressure rises to above $140 \mathrm{mmHg}$ and diastolic pressure reaches more than $90 \mathrm{mmHg}$ [2].

Hypertension will occur along with age [3]. The prevalence of hypertension in adults has reached approximately 1 billion, and is expected to increase in 2025 to 1.56 billion with drastic increase in developing countries such as Africa and Europe [4]. One third of the adult population of the Southeast Asian region can be ensured to have hypertension [5].

Doctors diagnoses related to adult hypertension population in 2018 reached $8.4 \%$ in Indonesia and this condition experienced a significant increase from 2013 to 2018 of $8.4 \%$. Central Java ranks the fourth highest prevalence of hypertension after South Kalimantan, West Java and East Kalimantan [6]. In Banyumas region, it is recorded that $55.79 \%$ of adults had hypertension in 2017 and the Kembaran I Public Health Center area became the region with the second highest number on hypertension incidence with 2887 cases [7].

The high incidence of hypertension requires appropriate and ongoing treatment to prevent further complications. Complications that can occur in patientss with hypertension include stroke, arteriosclerosis, heart attacks, and kidney failure [8]. The management of hypertension pharmacologically and non-pharmacologically is one of the right choices to control blood pressure so as to prevent the occurrence of these complications [9].

Based on research by Tawang, 2013 and Putra 2013, nonpharmacological treatment of patients with hypertension practicing slow-deep breathing shows a change in blood pressure in moderate to severe hypertension. Slow-deep breathing is a type of relaxation therapy that will reduce sympathetic nerve activity by increasing the inhibition of central rhythm [10]. The occuring barriers reduce the release of epinephrine which will be captured by alpha receptors and make smooth muscle from vasodilated blood vessels. The vasodilation process that occurs causes a decrease in peripheral resistance so that blood pressure decreases [11].

Another non-pharmacological therapy that is proven to reduce blood pressure is an isometric handgrip exercise. The research conducted by Pikkmann and Reisberg (2018) shows the existence of isometric handgrip exercises is considered to reduce blood pressure [12]. Isometric handgrip exercises are used to elicit cardiovascular responses [13]. Endothelial dysfunction that occurs in hypertensive patients will be resolved due to muscle contraction producing nitric oxide and increasing antioxidants. Moreover, it can reduce sympathetic nerve activity and increase cardiovascular capacity. As a result. myocardial oxygen demand will decrease [14].

Some studies on the effectiveness of isometric handgrip and slow-deep breathing on changes blood pressure of 
patients with hypertension has been conducted by several researchers. However, in some of these studies, there is none explaining which intervention is more effective.

The preliminary surveys conducted by researchers in Posbindu, Dukuh Wuluh Village, and the working area of Kembaran I Public Health Center, reveals that some Posbindu participants had hypertension for more than 2 years with uncontrolled blood pressure. They do not take any regular maintenance and some do bother the hypertension as a serious issue because they can still do their daily activities and will feel better after resting or sleeping. Posbindu participants have not also taken non-pharmacological therapy to help lowering their blood pressure.

Due the conditions mentioned above the conditions, researchers are interested in conducting a research related to the effect of slow-deep breathing and isometric handgrip on changes in blood pressure in patients with hypertension.

\section{SlOW-DeEP BREATHING AND ISOMETRIC HANDGRIP}

Slow-deep breathing is an act of relaxation by regulating deep and slow breathing. The relaxation response will be characterized by a decrease in pulse rate, breathing rhythm, a decrease in blood pressure and oxygen consumption [15]. Slow-deep breathing is performed in less than or equal to 10 times per minute (see Fig.1)

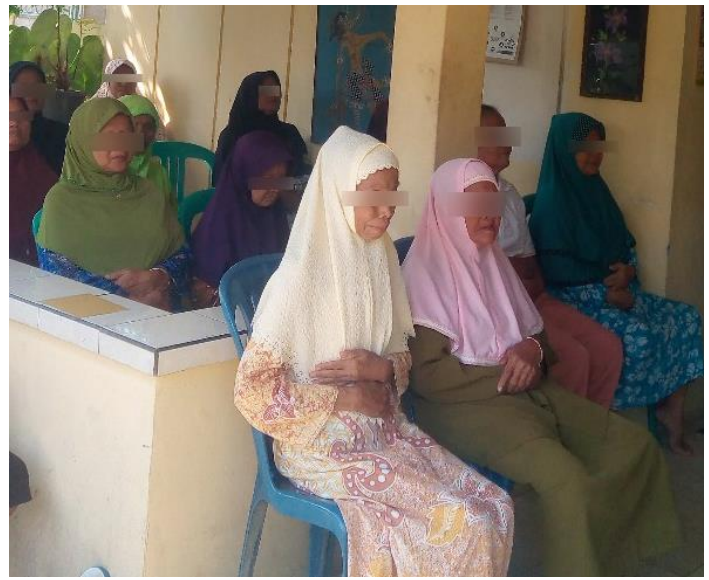

Fig. 1. Illustration of the Slow-deep breathing

Regular slow-deep breathing exercise will increase parasympathetic nerve response and decrease sympathetic nerve activity, improve respiratory and cardiovascular function, reduce the effect of stress, and improve physical and mental health [16].

Isometric handgrip is an exercise that can show cardiovascular response, and maintain normal blood pressure. Isometric handgrip exercise also results in a decrease in sympathetic nerve activity, increase cardiovascular capacity and reduce myocardial oxygen demand [17]. During isometric handgrip exercise, the chemoreceptor reflex is responsible for sympathetic nerve activity decreases and thus causes a weakening of the sympathetic nerve response affecting the sympathetic nerve activity which is responsible for decreasing blood pressure [18].

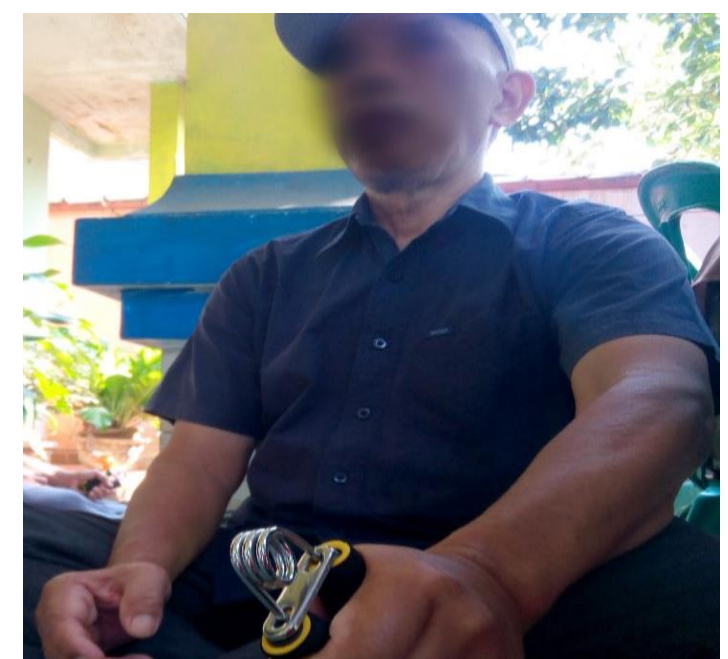

Fig. 2. Illustration of the isometric handgrip

\section{METHOD}

In this study, pretest and posttest design involving two groups was taken. The sampling technique used was purposive sampling. There were 40 respondents who were included in the study with the criteria of having systolic blood pressure and diastole $\geqslant 140 / 90 \mathrm{mmHg}$, age $\geqslant 18-16$ years, being able to hold a handgrip, not having arthritis, not having carpal tunnel syndrome, not having musculoskeletal injury in extremities and not having Diabetes Mellitus (DM)., and not having kidney failure.

The researchers divided 40 respondents into two groups: 20 respondents received an isometric handgrip intervention and 20 respondents used a slow-deep breathing intervention. The data were collected in June 2019 using a measuring instrument / instrument in the form of an observation sheet measuring blood pressure, Standart Operating Procedure (SOP) of isometric handgrip and slow-deep breathing, and a calibrated mercury sphygmomanometer.

Both groups received an intervention for 6 day. Blood pressure measurements were taken at the beginning of the intervention and after the intervention was done that is on the Day 6. Isometric handgrip exercises were done by sitting relaxedly, and the respondents held the handgrip for 45 seconds then opened their fists for 15 seconds. This exercise was done in both hands alternately with a total duration of 4 minutes of exercise.

Slow-deep breathing exercise was done by sitting relaxedly, breathing deeply for 6 minutes then resting for 10 seconds. This exercise is done for 15 minutes, and respondents can do 13 times slow deep-breathing. The Wilcoxon and Man Whitney test was used in this study to see the effect of interventions before and after, and to know the differences that occur in groups.

The researchers have received research approval from the Ethics Committee of Banyumas Hospital No. 006/KEPKSUDBMS/VI/2019 and obtained informed consent each respondent. 


\section{RESULT AND DISCUSSION}

The distribution of respondents in this study shows that respondents were predominantly female $(82.5 \%)$ who mostly have primary education degree $(70 \%)$ and the average of the respondents' age is 64 years. Before treatment, they had systolic pressure and diastole of an average of $159 / 98 \mathrm{mmHg}$ with the lowest blood pressure of $130 / 80 \mathrm{mmHg}$ and the highest of $210 / 130 \mathrm{mmHg}$. After treatment, they had blood pressure of systole and diastole with an average of 148/92 $\mathrm{mmHg}$, with the lowest blood pressure of 130/80 $\mathrm{mmHg}$ and the highest blood pressure of $180 / 120 \mathrm{mmHg}$.

The age of 64 years old can be categorized as elderly with high risk of experiencing health problems (Ministry of Health of the Republic of Indonesia, 2016). This is related to a decrease in the ability of cells in the body to replicate new cells, so that many cells die without new cells replacement [19].

TABLE I. CHARACTERISTIC OF RESPONDENTS BY SEX, FAMILY HISTORY, EDUCATION, AND OCCUPATIONS

\begin{tabular}{|c|c|c|}
\hline Variable & Frequency & $(\%)$ \\
\hline \multicolumn{3}{|l|}{ Gender } \\
\hline Female & 33 & 82,5 \\
\hline Male & 7 & 17,5 \\
\hline \multicolumn{3}{|l|}{ Education } \\
\hline Not in school & 4 & 10 \\
\hline Elementary & 28 & 70 \\
\hline Junior High School & 1 & 2,5 \\
\hline Senior High School & 7 & 17,5 \\
\hline
\end{tabular}

TABLE II. CHARACTERISTIC OF RESPONDENTS BY AGE, AND BLOOD PRESSURE BEFORE AND AFTER INTER VENTION

\begin{tabular}{|c|c|c|c|}
\hline Variable & Mean & SD & Min-Max \\
\hline Age & 64,55 & 11,177 & $46-92$ \\
\hline Previous Systole & 159 & 16,764 & $130-210$ \\
\hline Previous Diastole & 98 & 11,522 & $80-130$ \\
\hline Resulted Systole & 148 & 13,502 & $130-180$ \\
\hline Resulted Diastole & 92 & 13,502 & $80-120$ \\
\hline
\end{tabular}

Hypertension that occurs in the elderly is a result of unhealthy lifestyles that were done before such as smoking, rarely exercising, consuming too much fat and cholesterol and so on[20]. It results in stiffness and thickness of the heart valve accompanied by a decrease in the elasticity of the heart muscle and blood vessels so that blood supply throughout the body decreases. Fat accumulated on the artery walls will have an impact on increasing the workload of the heart so that the ability to pump blood is delayed and causes an increase in elderly blood pressure. The results of this study and theory can be concluded that age has a contribution to the incidence of hypertension. The older you get, the higher the chance of experiencing hypertension. The results showed that $82.5 \%$ of elderly women were detected to have hypertension. Theoretically, women have a greater risk of developing hypertension than men. This fact occurs due to a decrease in the estrogen and progesterone hormone which results in decreased blood vessel tone protection. When blood vessel tone protection decreases, the peripheral resistance will increase causing an increase in blood pressure [21].

This result is similiar to the research conducted by Kusumawaty, Hidayat and Ginanjar [22] stating that sex is closely related to hypertension, and middle-aged women will have a higher risk of developing hypertension. The research conducted by Tarigan, Lubis and Sarifah [23] also show that the prevalence of hypertension in women is higher than that of men with a ratio of $2: 1$.

Table 1 explains that some respondents were dominated by the level of elementary school education. It will affect the knowledge possessed by respondents, where higher education will have broader and deeper knowledge. Knowledge that needs to be retained by patients with hypertension includes the understanding of hypertension, causes, symptoms experienced, and the importance of taking regular and long-term treatment as well as the impact that can occur at any time if the treatment is stopped or does not longer consume the medicine [24]. This knowledge will lead to lead to the success of the treatment of hypertension [25].

TABLE III. EFFECT OF BLOOD PRESSURE BEFORE AND AFTER INTERVENTION

\begin{tabular}{|c|c|c|}
\hline Variable Test Result & Mann-Whitney & Wilcoxon \\
\hline Systole & 0,005 & 0,001 \\
\hline Diastole & 0,018 & 0,016 \\
\hline
\end{tabular}

The results of the analysis illustrated in table 2, show that the average of the respondent's age is 64 years old. Before treatment they had systolic pressure and diastole of an average of $159 / 98 \mathrm{mmHg}$ with the lowest blood pressure of $130 / 80 \mathrm{mmHg}$ and the highest of $210 / 130 \mathrm{mmHg}$. After treatment, they had blood pressure of systole and diastole with an average $148 / 92 \mathrm{mmHg}$, with the lowest blood pressure and the highest blood pressure of 180/120 $\mathrm{mmHg}$. Based on table 3, it is known that there is an effect of giving isometric handgrip intervention and slow-deep breathing on blood pressure of the patients with hypertension through different analytical tests.

The results of this study indicate that the influence of slow-deep breathing exercises and isometric hand grip with a decrease in systolic pressure with a value of $\mathrm{p}=0.005$ ( $\mathrm{p}$ $<0.05$ ) in patients with hypertension. Meanwhile, there is a decrease in the diastole pressure with a value of $\mathrm{p}=0.018$ ( $\mathrm{p}$ $<0.05)$ in patients with hypertension. These results are consistent with the research conducted by Wijayanti and Wulan which explains that when slow-deep breathing is performed, it will provide a sense of calm and relax so that it stimulates the release of CRH (corticotropin releasing hormone) and ACTH (adrebocortico trophic) hormone) [26]. The hormone expenditure that occurs makes the work activities of the sympathetic nerves decrease which results in a decrease in cardiac performance pressure and makes the body more relaxed [27].

A research conducted by Hartanti, et al show the effectiveness of breathing therapy in reducing blood pressure in hypertensive patients and this action does not cause any side effects or contraindications as in pharmacological treatment [28]. It is because the use of continuous pharmacological drugs will cause results in drugs dependency and worsen kidney function [29]. 


\section{CONCLUSION}

The conclusion obtained from this study is the average of respondents' aged 64 years old. Slow-deep breathing technique can only affect systolic blood pressure in patients with hypertension. However, it does not show any effect on diastolic blood pressure. The researchers suggest that nurses are expected to be able to provide slow-deep breathing intervention regularly and continuously to stabilize the blood pressure of patients with hypertension.

\section{REFERENCES}

[1] National Heart Foundation of Australia. 2016. Guidlane for the Diagnosis and Management of Hypertension in Adults 2016. Melbourne: NHFA 2016

[2] Hung, S. 2016. Elder Care: A Resouce for Interprofessional Provider. Arizona

[3] American Heart Association (AHA). 2016. Ejection Fraction Heart Failure Measurement. http://www.heart.org/HEARTORG/Conditions/HeartFailure/Sympto msDiagnosisofHeartFailure/ Ejection-Fraction-HearthFailureMeasurement_UCM_306339_Article.jsp\#.WAv-NeV97IX

[4] JAPI. 2016. Epidemiology of Hypertension. Supplement to JAPI. February 2013 Vol 61.

[5] World Health Organization. 2017. Cardiovascular diseases (CVDs).

[6] Riskesdas. 2018. Hasil Utama Riskesdas. Kementrian Kesehatan Badan Penelitian dan Pengembangan Kesehatan

[7] Dinas Kesehatan Kabupaten Banyumas. 2017. Kasus Penyakit Tidak Menular Di Pusksemas Dan Rumah Sakit Kabupaten/Kota Banyumas 2017. Purwokerto.

[8] Anderson, E, T. and McFarlane, J. 2011. Community As Patner Theory and Practice in Nursing (6th ed.). Philadelphia: Lippincott Williams \& Wilkins.

[9] Andri, Waluyo, Jumaiyah, Nasthasia. 2018. Efektivitas Isometric Handgrip Exercise dan Slow-Deep Breathing Exercise terhadap Perubahan Tekanan Darah Pada Penderita Hipertensi. Jurnal Keperawatan Silampari. Vol 2 No. 1 Desember 2018

[10] Tawang, E., dkk. 2013. Pengaruh Teknik Relaksasi Nafas Dalam Terhadap Penurunan Tekanan Darah Pada PAsien Hipertensi Sedang Berat Di RUang Irina C BLU Prof. DR. R. D. Kandau Manado. Ejournal keperawatan Vol 1. No 1, Agustus 2013

[11] Ikbal and Sari. 2018. The Effect of Slow-Deep Breathing on Blood Pressure of Hypertension Patients in M. Djamil Hospital Padang 2018 in The 1st Payung Negeri International Health Conference, KnE Life Sciences, pages 206-218. DOI 10.18502/kls.v4i10.3845

[12] Piikmann, Silvia., Reisberg, Kirkke. 2018. The Effect Of Isometric Handgrip Training On Blood Pressure. Acta Kinesiologiae Universitatis Tartuensis. 24: 109-120. https://doi.org/10/12697/akut.2018.24.08

[13] Bhavsar SD, Afroz S, Abhange RS. 2015. Evaluation of gender variation in cardiovascular response to isometric exercise in normal adolescents. IOSR-JDMS 14(5): 69-73

[14] Garg R, Malhotra V, Dhar U, Tripathi Y. 2013. The Isometric Handgrip Exercise as a test for Unmasking Hypertension in the offsprings of hypertensive e parents. Journal of Clinical and Diagnostic Research. 2013;7(6):996-99.

[15] Breathesy. 2007. Blood Pressure reduction : Frequently asked question, http:www.control-your-blood-pressure.com/faq.html

[16] Kiran, U., Behari, M., Venugopal, P., Vivekanandhan, S., \& Pandey, R.M. (2005). The Effect of Autogenic Relaxation on Chronic Tension Headache and in Modulating Cortisol Response. Indian J Anaesth, (49), 474-478

[17] Garg R, Malhotra V, Dhar U, Tripathi Y. 2013. The Isometric Handgrip Exercise as a test for Unmasking Hypertension in the offsprings of hypertensive e parents. Journal of Clinical and Diagnostic Research. 2013;7(6):996-99

[18] Kelley, George A, and Kristi S. Kelley. 2010. Isometric Handgrip Exercise and Resting Blood Pressure: a meta-analysis of randomized controlled trials. Journal of Hypertension. 2010;28(3):411-18.

[19] Mauk, K. L. 2014. Gerontological Nursing: Competencies For Care (3rd ed.).United States of America: Jones \& Bartlett Learning

[20] Johnson, J. Y. 2010. Handbook for Brunner \& Suddarth's Textbook of Medical Surgical Nursing 12 th ed. Philadelphia: Lippincott Williams \& Wilkins. https://doi.org/10.1002/15213773(20010316)40:6<9823::AID- ANIE9823>3.3.CO;2-C

[21] Smeltzer, S. C., Hinkle, J. L., Bare, B. G., \& Cheever, K. H. 2010. Textbook of Medical-Surgical Nursing (12th ed.). Philadelphia: Lippincott Williams \& Wilkins.

[22] Kusumawaty, Jajuk., Hidayat, Nur., Ginanjar, Eko. 2016. Hubungan Jenis Kelamin Dengan Intensitas Hipertensi Pada Lansia di Wilayah Kerja Puskesmas Lakbok Kabupaten Ciamis. Jurnal Mutiara Medika; 16(2): 46-51

[23] Tarigan, Almina Rospitaria., Lubis, Zulhaida., Syarifah. 2018. Pengaruh Pengetahuan, Sikap dan Dukungan Keluarga Terhadap Diet Hipertensi di Desa Hulur Kecamatan Pancur Batu Tahun 2016. Jurnal Kesehatan; 11(1). doi 10.24252/jkesehatan.v11il.5107

[24] Pramaestutie, Hananditia R., Silviana, Nina. 2016. Tingkat Pengetahuan Pasien Hipertensi Tentang Penggunaan Obat di Puskesmas Kota Malang. Jurnal Farmasi Klinik Indonesia; 5(1): 2634. doi 10.15416/ijcp.2016.5.1.26

[25] Sharma S., Bhuvan KC, Alrasheddy AA, Kuandinnyayana A, Khanals A. (2014). Impact of Community Pharmacy-Basec Educational Intervention on Patients With Hypertension In Western Nepal. Australasian Medical J; 7(7): 304-13. doi 10.4066/AMJ.2014.2133

[26] Wijayanti, Susi., Wulan, Emma Setiyo. (2017). Penurunan Tekanan Relaksasi Nafas Dalam Terhadap Penuruan Tekanan Darah Pada Pasien Hipertensi di RSUD dr. Loekmono Hadi Kudus. Proceding HEFA (Health Event of All), Kudus : 19 Agustus 2017. Hal 403 - 410

[27] Putra, E, K., Widodo, A., Kartinah. (2013). Pengaruh Latihan Nafas Dalam Terhadap Perubahan Tekanan Darah Pada Penderita Hipertensi di Wilayah Kecamatan Karas Kabupaten Magetan. Skripsi. Universitas Muhammadiyah Surakarta.

[28] Hartanti, R. D., Desannda, P.W., Rifqi, A.F. (2016). Terapi Relaksasi Nafas Dalam Menurunkan Tekanan Darah Pasien Hipertensi. Jurnal Ilmiah Kesehatan (JIK) Vol IX, No 1, Maret 2016. ISSN: 19783167

[29] Alimansur, M., Anwar, M.C. (2013). Efek Relaksasi Terhadap Penurunan Tekanan Darah Pada Penderita Hipertensi. Jurnal Ilmu Kesehatan Vol 2 No. 1, November 2013. ISSN: 23031433 